\title{
Investigation of Shale Gas Reserves in the World and A Case Study for Electricity Production from Shale Gas in Turkey
}

\author{
Erman Kadir Oztekin ${ }^{\mathbb{D}}$ Alperen Tozlu \\ Bayburt University, Department of Mechanical Engineering, Bayburt, Turkey
}

\section{ABSTRACT}

hale gas reserves, which is globally accepted as unconventional gas resource, scattered $\checkmark$ around the world and can be used in order to meet the growing energy needs due to limited amounts of conventional resources. Since notable effort has to be put in order to investigate and drill shale gas resources the early decision has to be made carefully, especially considering the economic benefits. Several factors must be considered including the known technically recoverable shale gas amount at the selected region, current technology to drill the shale source and the amount of investment before the extraction of shale gas. In this study, global underground shale gas amount and recent discoveries as well as the potential shale gas areas in Turkey are presented. Benefits of using shale gas for electricity generation and common methods being used during shale gas extraction are studied along with gas and liquid flow mechanisms. At the end, general overview of separation and utilization of shale gas components is schematically presented. In the case study, the potential of electricity generation in the SE Anatolia region in Turkey is estimated with only using methane obtained from the shale gas purification process at the power generation step. According to the estimations, $3337.8 \mathrm{MW}$ installed power may be generated for 50-55 years, at the appropriate gas engine by using 8.5 billion cubic meter shale gas annually.

Keywords:

Shale gas; Natural gas; Electricity generation; Global reserves; Gas engine

\author{
Article History: \\ Received: 2021/04/25 \\ Accepted: 2021/08/18 \\ Online: 2021/09/29 \\ Correspondence to: Erman Kadir Oztekin, \\ Bayburt University, Mechanical \\ Engineering, 6900o, Bayburt, TURKEY \\ E-Mail:ermanoztekin@bayburt.edu.tr \\ Phone: $+904582111153 / 1643$ \\ Fax: +904582111178
}

\section{INTRODUCTION}

\section{Shale Gas and Effective Factors in the Formation}

$\mathrm{T}$ oday many studies have been carried out to benefit from alternative energy reserves to meet the increasing energy needs and the depletion of conventional energy reserves in our world. Shale gas reserves have a large share among these unconventional energy reserves and have started to find an increasing

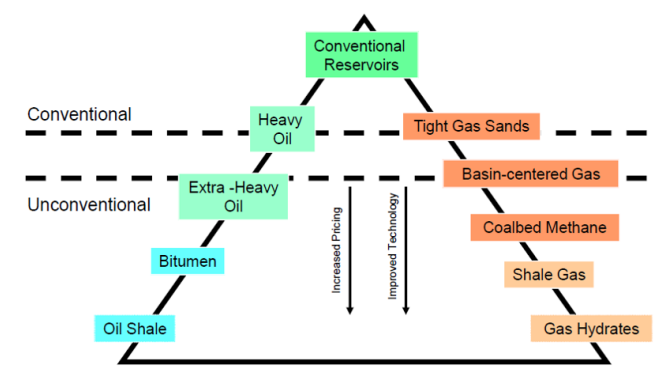

Figure 1. Classification of unconventional resources [7]. place in the literature [1-3]. Generally, 'unconventional gas' can be grouped in six classes namely; coalbed methane, tight gas, geopressured gas, gas hydrates, shale gas, and ultra-deep gas placed in different layers of the Earth's crust [4-6]. The termination of unconventional gas is highly depending on the technology for production however the classification can be schematically seen from Fig. 1 .

Shale gas is known as a compressed gas with rich hydrocarbon content that accumulates within shale formations of sedimentary rocks where these formations poses natural barrier to the migration of oil and gas. These gases are formed by the transformation of the contents of the residues remaining in the pores of the bedrock and later turned into gas form while the migration of natural gas and oil from the bedrock to different layers of Earth crust. Similarly, shale gas can be associated with natural gas trapped inside mudrocks that can be named as mudstone or shale and shale gas 


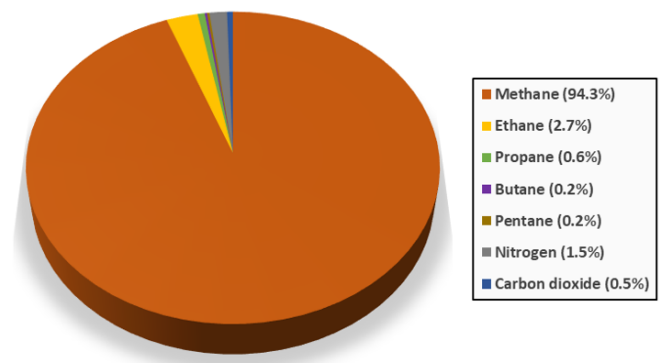

Figure 2. Volumetric averages of shale gas composition extracted in the US [12].

can be found in free, adsorbed and dissolved from in shale structure [8]. One of the most important factors affecting the accumulation shale gas in the solid structure are the porosity of the shale rock structure, the chemical content of the matrix and especially the amount of organic matter in this content $[9,10]$. The chemical content contains both organic, namely kerogen, and inorganic components such as clay minerals. Therefore, estimation of total permeability of the shale is essential for gas extraction [2]. The porosity of the shale matrix is estimated within the range from 5 to 10 percent [8]. After all required criteria are met mentioned earlier, rich shale target can be observed at shallow depths with a sufficient thermal maturity [5]. Gas flow is obtained through fractures so macroscopic properties of the gas flow such as permeability, adsorption and diffusivity are important.

Shale gas contains methane $\left(\mathrm{CH}_{4}\right)$ the most in its content where methane can be found as free gas under high pressure inside the fractures or pores and found in adsorbed phase in the bulk media of micropores in accordance with strong binding energy [11]. Averaged volumetric ratios of shale gas contents obtained in the U.S. can be seen on Fig 2. Methane and nitrogen are the major components in the typical shale gas along with propane, ethane, oxygen, and carbon monoxide [12]. Shale gas does not contain harmful hydrogen sulfide. It should be noted that shale gas content varies from basin to basin.

\section{Methods to Obtain Shale Gas and History of Development}

Appropriate methods have been implemented for obtaining shale gas. Among these methods, the horizontal drilling and hydraulic fracturing methods which are currently being used today and made it possible to extract shale gas efficiently $[13,14]$. Namely, these two methods have made it possible to obtain shale gas from places that previously would have been inaccessible [15]. In the hydraulic fracture method, the liquid, which is sent with high pressure and in a controlled manner, creates fractures and cracks in the structure of the rock and allows the gas inside to be collected. Depending on the scale of the drilling area, millions of gallons of water along with proppants such as; acid, mineral oil, iso propanol, ethylene glycol and sodium carbonate are sent with high pressure to the area where the trapped gas exist. The piping in this system is arranged to make the flow of fracture liquid and collected gas bidirectional and controlled. If necessary, cement and casing combination is mounted in the well. In this way, the groundwater in the region is protected. Similarly, horizontal drilling method is a technological method which allows long lines can be drawn in kilometers. During completion of shale gas wells both cement and casing can be used to protect underground water sources. The completely active first producing and commercial gas well in the U.S. was dated back to 1821 [15]. After a while, the UK drilled its first shale gas well in 1875 [5]. In 1976, the American Department of Energy initiated incentive projects for shale gas extraction, and as a result of successful projects, many companies have accelerated their shale gas extraction efforts since 2005 [16]. It can be argued that the technology used in the production of shale gas is a continuation of the technology implemented for natural gas production. It has been calculated that the shale gas production process can be completed in the most economical way when combining horizontal drilling and hydraulic fracturing methods [14]. By this way the permeability of the shale matrix can be increased. In addition, as previously stated, the management of the water used for shale gas production and the extra water coming from the well is important in terms of human health, environment and economy. The fluid moves along the cracks formed in the rough structure by obeying Darcy's law. Therefore, before the shale gas extracting event, the correct estimation of shale permeability is crucial [17]. Typical fracture patterns are considered during estimations such as; dead end, effective flow path and merged fractures. For example, in particular case dead end fractures may not be effective in fracture network in the rough structure. These types of studies somehow are not perfectly matched with real time data; thus, it was argued that the structure and effectiveness of kerogen, a macromolecule directly related with hydrocarbons in shales, in flow mechanisms should be understood for better model estimations [18].

\section{Shale Gas Transport Mechanisms}

Existence of highly porous media with pores formed in various scales and simultaneous multiple physicochemical processes lead to complex and transient flow characteristics during shale gas extraction $[8,19]$. Flow transport occurs in multiple mechanisms. Desorption of shale gas from walls of pores formed in different scales, diffusion of dissolved gas in kerogen medium and gas transport 


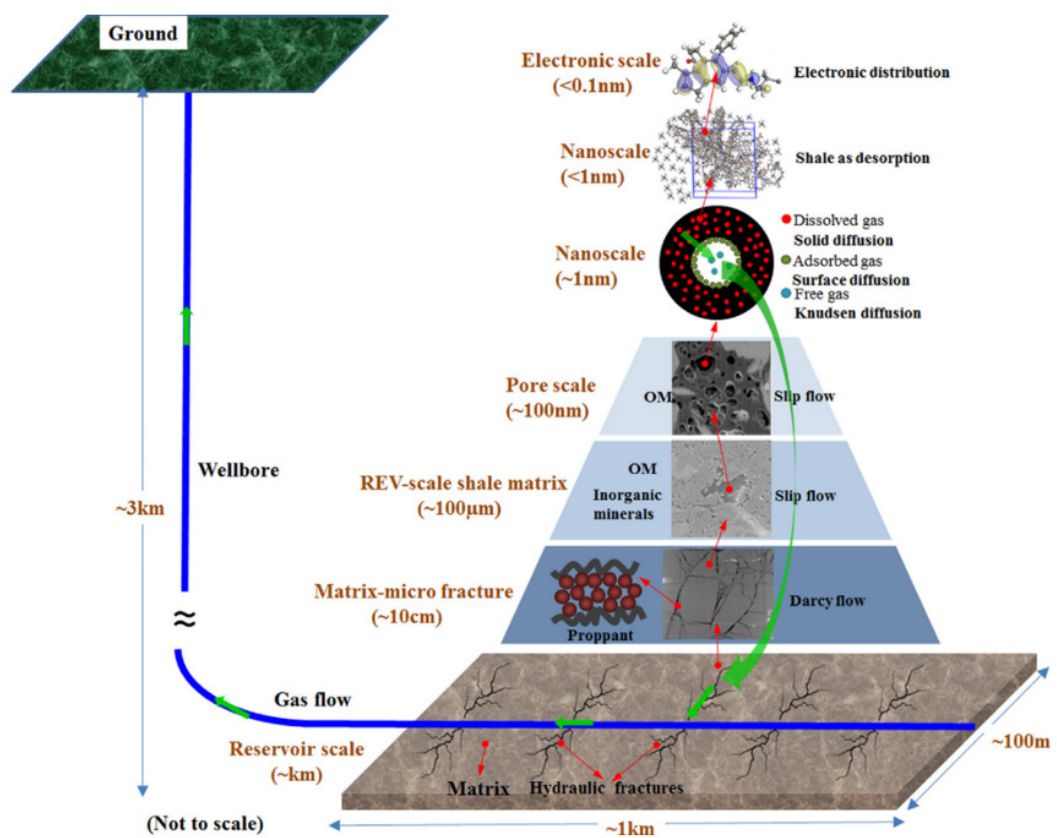

Figure 3. Detailed flow, diffusion, desorption and distribution processes during shale gas extraction [8].

from the boundaries of pores are governed with multiple physics laws such as Darcy flow, transition flow, Knudsen diffusion [8]. In addition, changing physical properties of pore medium during hydraulic fracturing, and nano scale effects in small pores lead to significantly confusing flow network during operation. The flow process can be summarized in Fig. 3. Understanding flow mechanism is essential in order to increase shale gas recovery during hydraulic fracturing [20-22]. For example injection of $\mathrm{CO}_{2}$ into fracture fluid may result in an increase methane recovery based on simulations $[20,23,24]$.

\section{ENERGY BENEFITS AND ENVIRONMENTAL ASPECTS OF SHALE GAS PRODUCTION}

The correct application of the techniques used in shale gas production, planning and qualified work are of great importance in terms of both energy gain and environmental factors [5]. Although the increasing shale gas production can close the energy gap of the countries, the United States has planned to increase the shale gas production to 50 percent of the total national gas production by 2030. Global shale gas production by the addition of other countries including Canada, Russia, India, Australia, countries of Europe and China will be expected to reach 32 percent of global natural gas production by 2035 .

Per thousand cubic feet of shale gas costs from $\$ 2$ to $\$ 3$ which is almost the half price of same amount of natural gas obtained from conventional gas wells [25]. The cheaper price of shale gas can eventually lead to cheaper electricity which can manifest itself in the annual economic growth. Increasing the shale gas production, which has a vast distribution on the basis of countries, can reduce the foreign dependence of countries on natural gas, i.e. the ever-increasing need of the European Union, and prevent foreign interventions in their economies $[25,26]$.

Opening and actively benefiting from gas wells eventually will lead to new job opportunities. For instance, in 2011, annual operation of Barnett Shale in Texas resulted in approximately $8 \%$ increase in the economy of the state, and supported $10 \%$ of regional employment [27].

In terms of environmental concerns shale gas has lower toxic gas emissions than fossil fuels [28, 29]. It can definitely be used for industrial purposes in terms of global warming concerns [30]. Commercial use of shale gas can offer cleaner atmosphere in countries where the industial use is highly dependent on oil and coal consumption [5].

As mentioned above before extraction of gas from a specific well, hydraulic fracturing operation require significant amount of water to be sent to target area with high pressure [31, 32]. For instance, annual water usage in Texas for three wells namely; Barnett Shale, Texas-Haynesville Shale, and Eagle Ford Shale was estimated to be equal of approximately 9 percent water consumption of 1.3 million people. And the injection of fluids does not include only water but also relatively significant amount of acids, surfactants, inhibitors, and friction reducers [33, 34]. So, the safety of the underground water sources should be considered and necessary precauti- 


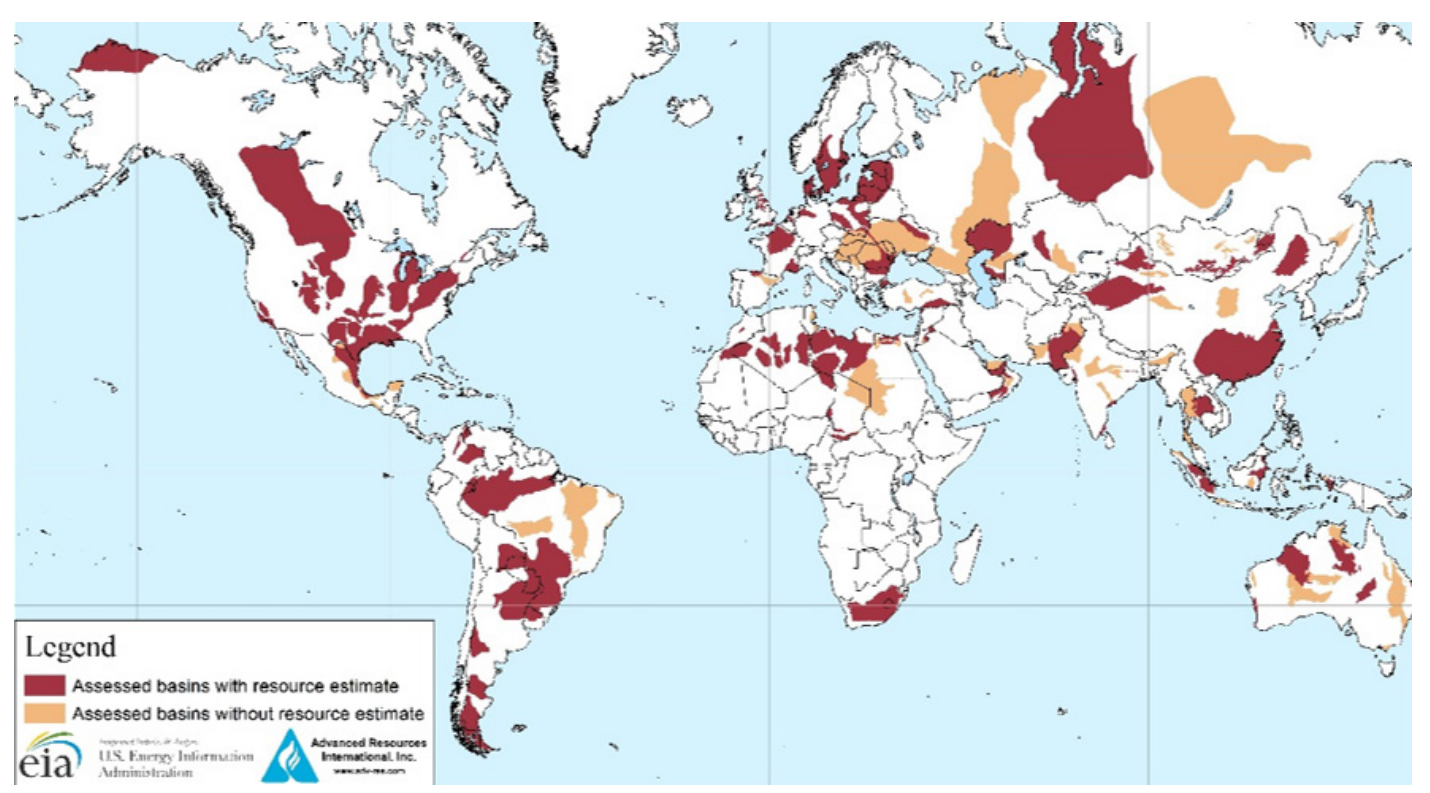

Figure 4. Map of basins with assessed shale oil and shale gas formations, as of May 2013 [42].

ons must be taken before and after drilling since these additives are posing danger to environment and they are known to be carcinogenic $[35,36]$. Thus several filtering methods have been employed to clean recovered water from wells [14, 37, 38]. Additionally, studies continue to investigate that the tremors that occur as a result of shale gas extraction trigger earthquakes [39-41].

\section{GLOBAL SHALE GAS PRODUCTION}

Shale gas resources spread in 42 countries worldwide, including U.S. that constitute 32 percent of the world's technically recoverable resources [42]. The Fig. 4 illustrates the major shale gas basins distributed around the world. It can be concluded that the presence of the source is vast and can be economically benefited by production in huge amounts.

Moreover, since most of the countries have the potential for gas production, many countries can meet the energy needs. For example, U.S. Energy Information Administration released a report that U.S. had significant amount of proved reserves containing approximately 342.1 trillion cubic feet shale gas in 2018 and later this value has increased to 353.1 trillion cubic feet in 2019 [43]. Moreover, every year the amount of proved natural gas reserves tend to increase along with the shale gas share in the total with new discoveries. The annual shale gas production in the U.S. was $0.3 \mathrm{tcf}$ in 2000 and it was taken off to $4.8 \mathrm{tcf}$ in 2010 and eventually reached up to $9.6 \mathrm{tcf}$ in 2012 [44]. The annual production of The Barnett Shale in Texas alone was approximately $0.5 \mathrm{tcf}$ of natural gas in 2005 [42]. Fig. 5 shows the growth of U.S. total natural gas proved reserves (shale and other sources) from 2012 to 2019 .
According to the world data, Russia has the most technically recoverable shale oil resources in the world [42]. United States, China, Argentina and Libya are also listed in the first five countries which have the most technically recoverable shale oil resources in the world. Although studies on shale gas basins generally deal with calculations for certain countries, there are still not enough studies for regions with rich underground resources such as the Caspian region and Middle East [5]. Today, at least 60 years of energy need of the world can be met with the technically recoverable shale oil and gas reserves known in our world [14]. There is no Globally accepted shale gas investigation method but U.S. Energy Information Administration set specific standards, that is, shale formations can be assessed based on a combination of factors such as availability of data, natural gas import dependence of a nation, observed large shale formations, and efforts by companies and governments directed

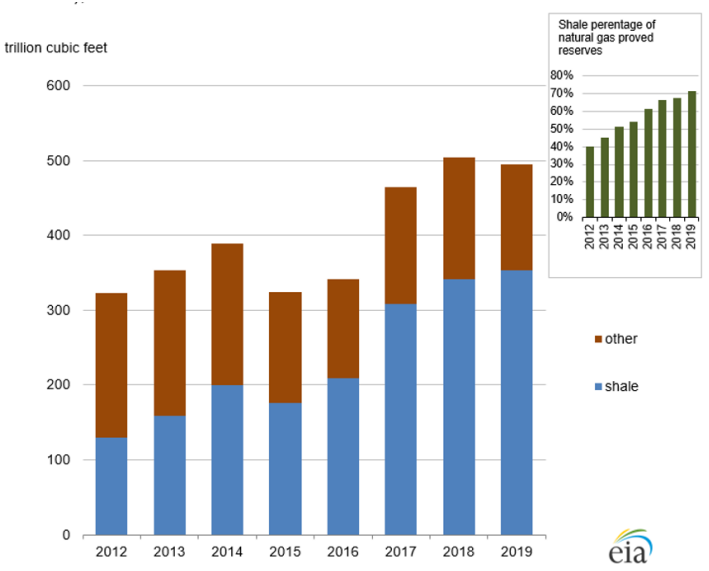

Figure 5. Proved natural gas reserves of the U.S. (shale and other sources), from 2012 to 2019 [43]. 
at shale resource development [42]. Moreover, obtained data from Argentina promise a future in shale gas production [45]. The natural gas production potential of Argentina has been steadily increasing for the last three years due to high capacity at the Neuquén Basin's Vaca Muerta shale and tight gas play. At Neuquén Basin, with 583 tcf technically recoverable shale gas reserve, 29 thousand cubic meters of shale gas produced in one day.

\section{SHALE GAS PRODUCTION POTENTIAL OF TURIEY}

According to U.S. Energy Information Administration report Turkey has 24 tcf EIA/ARI unproved wet shale gas and 4700 million barrels EIA/ARI unproved shale oil technically recoverable resources in 2013 [42]. Map of major shale basins in Turkey can be seen on Fig. 6. Turkey has two major approved basins, SE Anatolian (Dadas shale) and Thrace (Hamitabat shale) with 17 and 6 tcf technically recoverable shale gas and 4.6 and 0.1 Billion bbl technically recoverable shale oil, respectively. Turkish national petroleum company (TPAO) and several international companies have still ongoing research and drilling operation on these two major basins.

Salt Lake basin and Sivas basin are predicted to have also shale production potential when examining the geological details but still more data is required for certain predictions. The Southeast Anatolia Basin, covering 32,100 square meters area, is located at south-east side of Turkey and is adjacent to Iraq and Syria. First well was opened by Anatolia Energy in 2012 [46]. The Thrace Basin, covering 6,500 square meters area, is located at north-west side of Turkey and bordered with several massif areas including Istranca Massif, the Rhodope Massif and the Sakarya Massif. The basin is Turkey's primary natural gas producing area with approximately 350 wells.

Shell and TPAO partnership started in shale gas exploration works in Diyarbakır, Silvan, initially Joint Venture Agreements contract was signed in 2011 [45]. In 2015, calculated total technically recoverable shale gas resources was estimated, approximately $15 \mathrm{tcf}$, lower than current data

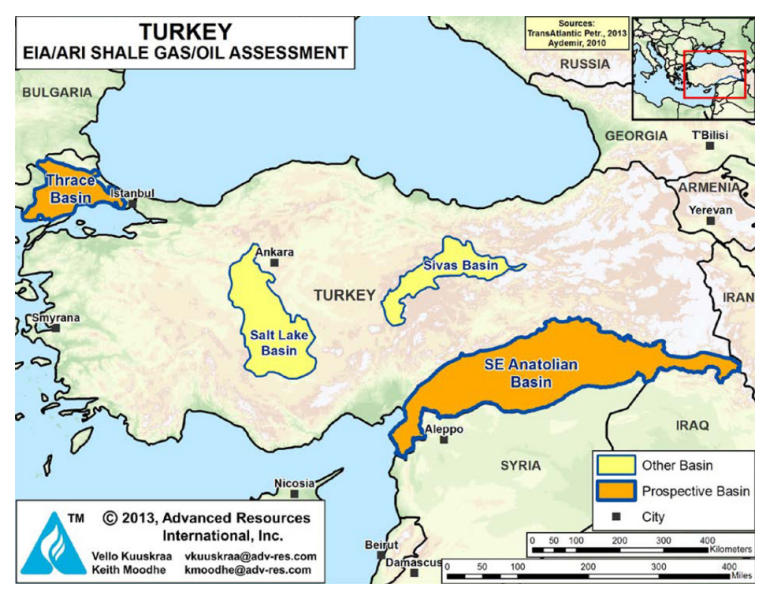

Figure 6. Major Shale Basins of Turkey [42].

and it was estimated that the reserve, estimated in 2015, corresponds to Turkey's energy needs for 30 years [47]. Later, Shell company left the project in 2016 [45]. As a result, it was determined that Turkey has processible shale gas formations with suitable mudstone depth and rocks with sufficient mineral compositions for the formation of shale gas and available for hydraulic fracturing usage.

\section{CASE STUDY: ELECTRICITY GENERATION IN SE ANATOLIAN BASIN}

Since shale gas is an important alternative fuel source, the results of its possible use for electricity generation in our country should be evaluated carefully. In this context, the stages from shale gas extraction to electricity generation are schematically presented in Fig. 7 to create a general impression for the reader. As seen in the Fig. 7, by-products produced from shale gas at different stages can be used for several reasons. At the end of the designed process, electricity generation can be accomplished at the power plant with selection of appropriate engines.

Herein, as a case study, the electricity generation potential of SE Anatolia region with 481.3 billion cubic meter technically recoverable shale gas is evaluated by utilization of methane output [42]. Several methods have already been developed to produce electricity from unconventional
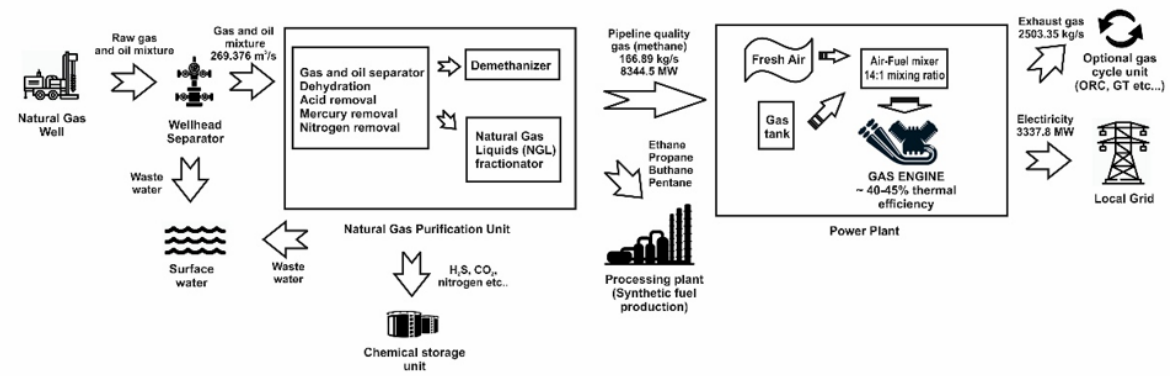

Figure 7. General scheme of shale gas separation and utilization. 
energy sources [48-51]. Diesel engines and gas engines are widely used in energy industry [52-56]. Since Turkey is still in a need for investment in shale gas exploration and drilling, the annual shale gas production in SE Anatolia region is considered to be approximately 8.5 billion cubic meter which is similar to US production in 2000 when US is not yet very experienced in shale gas production [44]. This corresponds to approximately 50 to 55 years of shale gas production for this case study. This estimated time frame is in line with the previous estimates for Turkey's energy demand from shale gas $[45,47]$.

As seen from Fig. 7, the water used for hydraulic fracturing is initially separated from wellhead and the remaining gas-oil mixture is sent to purification stage in order to be delivered to mainline transmission systems and to meet necessary quality standards. Some of by-products produced from purification stage such as acids, nitrogen can be either stored or utilized for specific reasons since they are still valuable in chemical industry. Accordingly, natural gas liquids (NGL) can be further processed to obtain synthetic fuels. NGL products are valuable in fuel industry $[57,58]$ Moreover they can be used as alternative fuel especially methanol [59]. Pipeline gas (methane) is obtained in the last step of purification stage. Composition of shale gas can slightly change from basin to basin but methane is still the dominant component of the shale gas. For this study $94 \%$ of the shale gas composition is considered to be pure methane which is similar with the average shale gas composition in US basins [12]. This amount is approximately corresponding to methane mass flow ratio of $166.89 \mathrm{~kg}$ per second. In power plant several common types of gas engines can be employed to produce electricity power. The thermal efficiency of gas engines operating using natural gas is generally between 40 and 45\% [60-64]. Here 40\% thermal efficiency is considered to produce electric power. And also, methane gas is mixed with 14 times more air. 3337.8 MW installed power is calculated. Relatively huge amount of exhaust gas is obtained during electricity generation. The temperature of the exhaust gas can vary with respect to engine type but it can be argued that the temperature of the exhaust gas will be around $400^{\circ} \mathrm{C} \sim 500^{\circ} \mathrm{C}$ [65-67]. Thus, the exhaust gas which contains considerable amount of thermal energy can be further utilized in several gas cycles such as Organic Rankine Cycle (ORC), Gas Turbine Cycle (GT) for further electric power production [68-72].

\section{CONCLUSION}

In this study, the amount of available shale gas and developments across the world and in Turkey has been examined. Additionally, the flow mechanisms of the shale gas wells are presented. The results and the comments that can be made can be listed as follows:
- Shale gas exploration and drilling activities continue around the world and are supported by new investments.

- In addition to countries with large shale gas reserves such as America and China, countries such as Argentina come to the fore with their reserves in the light of new studies.

- $\quad$ Turkey needs new investments to cover the high costs of shale gas drilling and production. Thus, developing technology in shale gas exploration and drilling will be an important factor in reducing costs and in determining Turkey's shale gas extraction targets.

- $\quad$ The estimated amount of shale gas reserves in Turkey is 679 billion cubic meter which is very small compared to the dominant countries in the world in terms of shale gas reserves. For instance, Argentina's Neuquén Basin alone has 24 times more shale gas reserves.

- In this case study it has been put forward that 3337.8 MW installed power may be generated by using 8.5 billion cubic meter shale gas annually for $50-55$ years only in SE Anatolia region. According to the data presented in the first half of 2021, the installed capacity of power plants in Turkey is 92,798 MW [73]. The calculated electric power from shale gas corresponds to $3.6 \%$ of Turkey's current capacity.

- The positive returns of by-products obtained from shale gas can be quantified in future studies. In addition, it can be investigated whether the extra power that can be obtained by the use of exhaust gases will also be beneficial to the total power.

- Depending on newly discovered shale gas resources and their capacities in Turkey, total possible electric power generation can be re-calculated in future studies.

\section{ACKNOWLEDGEMENT}

Authors gratefully acknowledge Bayburt University for providing their software facilities and constant interests in this study.

\section{CONFLICT OF INTEREST}

Authors approve that to the best of their knowledge, there is not any conflict of interest or common interest with an institution/organization or a person that may affect the review process of the paper. 


\section{AUTHOR CONTRIBUTION}

All section including conceptualisation, methodology, software, analysis, writing, review and editing were equally organised and performed by Erman Kadir Oztekin and Alperen Tozlu.

\section{References}

1. Mastalerz, M., A. Drobniak, and A.B. Stankiewicz, Origin properties, and implications of solid bitumen in source-rock reservoirs: A review. International Journal of Coal Geology. 195 14-36, 2018.

2. Cui, J. and K. Wu, Equivalent permeability of shale rocks: Simple and accurate empirical coupling of organic and inorganic matter. Chemical Engineering Science. 216, 115491, 2020.

3. Estrada, J.M. and R. Bhamidimarri, A review of the issues and treatment options for wastewater from shale gas extraction by hydraulic fracturing. Fuel. 182, 292-303, 2016

4. Hackley, P.C. and B.J. Cardott, Application of organic petrography in North American shale petroleum systems: A review. International Journal of Coal Geology. 163, 8-51, 2016.

5. Sovacool, B.K., Cornucopia or curse? Reviewing the costs and benefits of shale gas hydraulic fracturing (fracking). Renewable and Sustainable Energy Reviews. 37, 249-264, 2014.

6. Davies, R.J., et al., Oil and gas wells and their integrity: Implications for shale and unconventional resource exploitation. Marine and Petroleum Geology. 56, 239-254, 2014.

7. Chan, P., J.R. Etherington, and R. Aguilera, A Process to Evaluate Unconventional Resources. Paper presented at the SPE Annual Technical Conference and Exhibition, Florence, Italy, September 2010.

8. Wang, H., et al., Modeling of multi-scale transport phenomena in shale gas production - A critical review. Applied Energy. 262, 114575, 2020.

9. Gale, J.F.W., et al., Natural fractures in shale: A review and new observations. Aapg Bulletin. 98(11), 2165-2216, 2014.

10. Ross, D.J.K. and R. Marc Bustin, The importance of shale composition and pore structure upon gas storage potential of shale gas reservoirs. Marine and Petroleum Geology. 26(6), 916-927, 2009

11. Dang, W., et al., Investigation of gas content of organic-rich shale: A case study from Lower Permian shale in southern North China Basin, central China. Geoscience Frontiers. 9(2), 559-575, 2018.

12. Korpyś, M., J. Wójcik, and P. Synowiec, Methods for sweetening natural and shale gas. Chemik Science-Technique-Market. 68, 213 215, 2014.

13. Stephanie, M.R., et al., Hybrid membrane bio-systems for sustainable treatment of oil and gas produced water and fracturing flowback water. Separation and Purification Technology. 171, $297-$ $311,2016$.

14. Chang, H.Q., et al., Potential and implemented membrane-based technologies for the treatment and reuse of flowback and produced water from shale gas and oil plays: A review. Desalination. 455, 34 57, 2019.

15. Ground Water Protection Council, Modern Shale Gas Development In The United States: A Primer, U.S. Department of Energy, Office of Fossil Energy, National Energy Technology Laboratory (NETL), Oklahoma City, OK, 2009.

16. Gregory, K.B., R.D. Vidic, and D.A. Dzombak, Water Management Challenges Associated with the Production of Shale Gas by Hydraulic Fracturing. Elements. 7(3), 181-186, 2011.
17. Chen, D., Z. Pan, and Z. Ye, Dependence of gas shale fracture permeability on effective stress and reservoir pressure: Model match and insights. Fuel. 139, 383-392, 2015.

18. Agrawal, V. and S. Sharma, Are we modeling the properties of unconventional shales correctly? Fuel. 267, 117316, 2020.

19. Javadpour, F., D. Fisher, and M. Unsworth, Nanoscale Gas Flow in Shale Gas Sediments. Journal of Canadian Petroleum Technology. 46(10), 2007.

20. Iddphonce, R., J.J. Wang, and L. Zhao, Review of CO2 injection techniques for enhanced shale gas recovery: Prospect and challenges. Journal of Natural Gas Science and Engineering. 77, 12, 2020 .

21. Liu, J., et al., Numerical evaluation on multiphase flow and heat transfer during thermal stimulation enhanced shale gas recovery. Applied Thermal Engineering. 178, 16, 2020.

22. Huang, L., et al., Effect of organic type and moisture on $\mathrm{CO} 2 /$ $\mathrm{CH} 4$ competitive adsorption in kerogen with implications for $\mathrm{CO} 2$ sequestration and enhanced $\mathrm{CH} 4$ recovery. Applied Energy. 210, 28-43, 2018

23. Rani, S., E. Padmanabhan, and B.K. Prusty, Review of gas adsorption in shales for enhanced methane recovery and $\mathrm{CO} 2$ storage. Journal of Petroleum Science and Engineering. 175, 634-643, 2019.

24. Hu, X., et al., Thermodynamic effects of cycling carbon dioxide injectivity in shale reservoirs. Journal of Petroleum Science and Engineering. 195, 7, 2020.

25. Deutch, J., The Good News About Gas: The Natural Gas Revolution and Its Consequences. Foreign Affairs. 90(1), 82-93, 2011.

26. Tuğan, M.F., Assessing Uncertainties And Managing Risks In Shale Gas Projects, PhD thesis in Petroleum and Natural Gas Engineering Department. Middle East Technical University, Ankara, 2017.

27. House, E.J., Fractured Fairytales: The Failed Social License for Unconventional Oil and Gas Development. Wyoming Law Review. $13,2013$.

28. Wei, L.J. and P. Geng, A review on natural gas/diesel dual fuel combustion, emissions and performance. Fuel Processing Technology. 142, 264-278, 2016.

29. Burnham, A., et al., Life-cycle greenhouse gas emissions of shale gas, natural gas, coal, and petroleum. Environ Sci Technol. 46(2), 619-27, 2012.

30. Adgate, J.L., B.D. Goldstein, and L.M. McKenzie, Potentia Public Health Hazards, Exposures and Health Effects from Unconventional Natural Gas Development. Environmental Science \& Technology. 48(15), 8307-8320, 2014.

31. Vengosh, A., et al., A Critical Review of the Risks to Water Resources from Unconventional Shale Gas Development and Hydraulic Fracturing in the United States. Environmental Science \& Technology. 48(15), 8334-8348, 2014.

32. Nicot, J.P. and B.R. Scanlon, Water use for Shale-gas production in Texas, U.S. Environ Sci Technol. 46(6), 3580-6, 2012.

33. Stringfellow, W.T., et al., Physical, chemical, and biological characteristics of compounds used in hydraulic fracturing. Journal of Hazardous Materials. 275, 37-54, 2014.

34. Howarth, R.W., A. Ingraffea, and T. Engelder, Natural gas: Should fracking stop? Nature. 477(7364), 271-5, 2011.

35. Kahrilas, G.A., et al., Biocides in Hydraulic Fracturing Fluids: A Critical Review of Their Usage, Mobility, Degradation, and Toxicity. Environmental Science \& Technology. 49(1), 16-32, 2015.

36. Warner, N.R., et al., Impacts of Shale Gas Wastewater Disposal on Water Quality in Western Pennsylvania. Environmental Science \& Technology. 47(20), 11849-11857, 2013.

37. Al-Ghouti, M.A., et al., Produced water characteristics, treatmen and reuse: A review. Journal of Water Process Engineering. 28, 222- 
239, 2019.

38. Shaffer, D.L., et al., Desalination and Reuse of High-Salinity Shale Gas Produced Water: Drivers, Technologies, and Future Directions. Environmental Science \& Technology. 47(17), 9569-9583, 2013.

39. Li, L., et al., A review of the current status of induced seismicity monitoring for hydraulic fracturing in unconventional tight oil and gas reservoirs. Fuel. 242, 195-210, 2019.

40. Costa, D., et al., Extensive review of shale gas environmental impacts from scientific literature (2010-2015). Environmental Science and Pollution Research. 24(17), 14579-14594, 2017.

41. Ellsworth, W.L., Injection-Induced Earthquakes. Science. 341(6142), 2013.

42. U.S. Energy Information Administration, Technically Recoverable Shale Oil and Shale Gas Resources: An Assessment of 137 Shale Formations in 41 Countries Outside the United States. U.S Department of Energy, Washington, DC, 2013.

43. U.S. Energy Information Administration, Proved Reserves of Crude Oil and Natural Gas in the United States, Year-End 2019. U.S. Department of Energy, Washington, DC, 2021.

44. Hao, F., H. Zou, and Y. Lu, Mechanisms of shale gas storage: Implications for shale gas exploration in China. AAPG Bulletin. 97, 1325-1346, 2013

45. Derman, A., Unconventional Resources in Turkey: Myth or Reality? Energy Policy Turkey. (3), 75 - 87, 2017.

46. Anatolia Energy, Unlocking Turkey's Shale Resources. March, 2013

47. Karsli, S.l., Shale Gas in Turkey According to the Latest Developments. Journal of the Institute of Science and Technology. 5(3), 2015.

48. Raj, N.T., S. Iniyan, and G. Ranko, A review of renewable energy based cogeneration technologies. Renewable and Sustainable Energy Reviews. 15(8), 3640-3648, 2011.

49. Ayşegül, A., S. Demir, and M. Kanoğlu, Biyogaz Beslemeli Gaz Motorlu Bir Kojenerasyon Sisteminin Termoekonomik Analizi. Is Bilimi ve Tekniği Dergisi. 33(2), 9-21, 2013.

50. Michele, B., B. Lisa, and Andrea, Combining waste-to-energy steam cycle with gas turbine units. Applied Energy. 130, 764-773, 2014.

51. Mehmet, K.l., Süleyman, and A.l. Ayşegül, Performance characteristics of a Diesel engine power plant. Energy Conversion and Management. 46(11), 1692-1702, 2005.

52. Duc Luong, C., H. Guang, and L. Anh Tuan, Applying chemical heat storage to saving exhaust gas energy in diesel engines: Principle, design and experiment. Journal of Energy Storage. 28, 101311, 2020

53. Ting, H. and L. Wensheng, Energy saving research of natural gas liquefaction plant based on waste heat utilization of gas turbine exhaust. Energy Conversion and Management. 225, 113468, 2020.

54. Dmitry, P., Energy optimization analysis of a thermochemical exhaust gas recuperation system of a gas turbine unit. Energy Conversion and Management. 171, 917-924, 2018.

55. Junjiang, B. and Z. Li, A review of working fluid and expander selections for organic Rankine cycle. Renewable and Sustainable Energy Reviews. 24, 325-342, 2013.

56. Olumide, O., W. Meihong, and K. Greg, Closed-cycle gas turbine for power generation: A state-of-the-art review. Fuel. 180, 694-717, 2016.

57. Wood, D.A., C. Nwaoha, and B.F. Towler, Gas-to-liquids (GTL): A review of an industry offering several routes for monetizing natural gas. Journal of Natural Gas Science and Engineering. 9, 196-208, 2012.

58. Yeşilyurt, M.K., An Experimental Study On The Performance And Exhaust Emission Characteristics Of A CI Engine Powered By Alcohol/Biodiesel/Diesel Fuel Blends Containing Different Types Of Alcohol (Isopropanol-C3, 1-Butanol-C4, And Isopentanol-C5). Hittite Journal of Science and Engineering. 7(2), 135-148, 2020.

59. Zhen, X.D. and Y. Wang, An overview of methanol as an internal combustion engine fuel. Renewable \& Sustainable Energy Reviews. 52, 477-493, 2015.

60. Thomson, H., J.J. Corbett, and J.J. Winebrake, Natural gas as a marine fuel. Energy Policy. 87, 153-167, 2015.

61. Emrah, Ö. and T. Alperen, Optimization of an adapted Kalina cycle to an actual municipal solid waste power plant by using NSGA-II method. Renewable Energy. 149, 1146-1156, 2020.

62. Özahi, E., A. Tozlu, and A. Abusoglu, Organik Rankine çevrimi entegre edilmiş S-CO2 kullanılan bir gaz türbin çevriminin termodinamik ve termoekonomik analizi. Gazi Üniversitesi Mühendislik-Mimarlık Fakültesi Dergisi, 33(3), 2018.

63. Alperen, T., A. Ayşegül, and Ö. Emrah, Thermoeconomic analysis and optimization of a Re-compression supercritical CO2 cycle using waste heat of Gaziantep Municipal Solid Waste Power Plant. Energy. 143, 168-180, 2018.

64. Emrah, Ö., T. Alperen, and A. Ayşegül, Thermoeconomic multiobjective optimization of an organic Rankine cycle (ORC) adapted to an existing solid waste power plant. Energy Conversion and Management. 168, 308-319, 2018.

65. Emrah, O., A. Aysegul, and T. Alperen, A comparative thermoeconomic analysis and optimization of two different combined cycles by utilizing waste heat source of an MSWPP. Energy Conversion and Management. 228, 113583, 2021.

66. Aysegul, A., T. Alperen, and A.-M. Amjad, District heating and electricity production based on biogas produced from municipal WWTPs in Turkey: A comprehensive case study. Energy. 223, 119904, 2021.

67. Tozlu, A., Y. Büyükmurat, and E. Özahi, Thermoeconomic analyses of an actual power plant. Turkish Journal of Electromechanics \& Energy. 5(1), 2020.

68. Bertrand, M. Pétrissans, and G. Papadakis, Heat resources and organic Rankine cycle machines. Renewable and Sustainable Energy Reviews. 39, 1185-1199, 2014.

69. Karaali, R. and İ.T. Öztürk, Analysis of Steam Injection into Combustion Chamber of Gas Turbine Cogeneration Cycles Hittite Journal of Science and Engineering. 5, 2018.

70. Kilicarslan, A. and M. Kiris, Exergy Destruction Analysis of a Gas Turbine Power Plant. Hittite Journal of Science and Engineering. 5(4), 339-346, 2018.

71. Sarac, B. and T. Ayhan, Exergy Thermodynamic Analysis of Effects of the Inlet Air Cooling on Cycle Performance in Combined Brayton-Diesel Cycle. Hittite Journal of Science and Engineering. 7(1), 2020.

72. Balku, S., Thermal Efficiency Optimization for A Natural-Gas Power Plant. Hittite Journal of Science and Engineering. 4(2), 151157, 2017.

73. Yılmaz, A. Enerji Atlası. Access time: 13 March 2021. Available from: https://www.enerjiatlasi.com/. 